\title{
Late Glacial to Holocene Indian Summer Monsoon Variability Based upon Sediment Records Taken from the Bay of Bengal
}

\author{
Harunur Rashid ${ }^{1, *}$, Emily England ${ }^{1}$, Lonnie Thompson $^{1,2}$, and Leonid Polyak ${ }^{1}$ \\ ${ }^{I}$ Byrd Polar Research Center, The Ohio State University, Columbus, Ohio, USA \\ ${ }^{2}$ School of Earth Sciences, The Ohio State University, Columbus, Ohio, USA
}

Received 1 March 2010, accepted 17 September 2010

\begin{abstract}
Paleoclimatic records from the Bay of Bengal are rare. We reconstruct the sea-surface temperature (SST) and salinity from paired $\delta^{18} \mathrm{O}$ and $\mathrm{Mg} / \mathrm{Ca}$ measurements in planktonic foraminifera Globigerinoides ruber from the western Bay of Bengal core VM29-19. Our data suggest that SST and seawater $\delta^{18} \mathrm{O}\left(\delta^{18} \mathrm{O}_{\mathrm{sw}}\right)$ were $\sim 3^{\circ} \mathrm{C}$ colder and $\sim 0.6 \%$ depleted, respectively, during the Last Glacial Maximum (LGM) compared to the early Holocene. The most enriched $\delta^{18} \mathrm{O}_{\text {sw }}$ values were found between 18.2 and $15.6 \mathrm{ka}$ interval. Depleted $\mathrm{LGM} \delta^{18} \mathrm{O}_{\mathrm{sw}}$ values suggest a wet climate which freshened the Bay of Bengal sea surface. Our data further indicate that the monsoon was stronger in the Bølling/Allerød and weaker in the Younger Dryas periods. The most depleted early Holocene $\delta^{18} \mathrm{O}_{\mathrm{sw}}$ values suggest that the monsoon was stronger and wetter resulting in a humid climate. After $\sim 5$ ka the Indian summer monsoon weakened significantly, indicating less dilution of the sea surface by the Ganges-Brahmaputra-Meghna outflow and/or less direct rainfall. We hypothesize that the prevailing late Holocene dry climate may have caused the diminishment and subsequent abandonment of the settlements of the great Indus Valley Civilizations. Our Bay of Bengal climate records are consistent with those from the Andaman Sea, corroborating broad regional changes in the Indian summer monsoon during the last $25 \mathrm{ka}$. The general pattern and timing of monsoon variability in the Bay of Bengal and Andaman Sea seems to parallel the Arabian Sea, Africa, and Asian ice cores and speleothem records suggesting that a common tropical forcing may have induced these abrupt climate changes.
\end{abstract}

Key words: Indian summer monsoon, Climate change, Demise of ancient civilizations

Citation: Rashid, H., E. England, L. Thompson, and L. Polyak, 2011: Late glacial to Holocene Indian summer monsoon variability based upon sediment records taken from the Bay of Bengal. Terr. Atmos. Ocean. Sci., 22, 215-228, doi: 10.3319/TAO.2010.09.17.02(TibXS)

\section{INTRODUCTION}

The Indian summer monsoon (ISM) is a dynamic climate system, which brings enormous changes in the hydrological cycle during the summer (Gadgil 2003; Cane 2010). The ISM is the product of a pressure difference resulting from tropospheric heating between the high Tibetan Plateau and tropical Indian Ocean. This seasonal low atmospheric pressure at the Tibetan Plateau relative to higher pressure over the cooler Indian Ocean sets the stage for the cyclonic summer-monsoon wind patterns (Webster et al. 1998; Rashid et al. 2007). The cyclonic wind intensifies upwelling at the Somali margin, bringing up cold, nutrient rich waters that stimulate high productivity (Honjo et al. 1999; Heinz

\footnotetext{
* Corresponding author

E-mail:rashid.29@osu.edu
}

and Hemleben 2006; Rao et al. 2010). Evaporation from the tropical Indian Ocean adds moisture and latent heat intensifying the ISM (Shankar et al. 2002). On annual to decadal time scales monsoon intensity is influenced by changes in internal boundary conditions such as tropical Indian Ocean sea surface temperatures (SSTs) (Webster et al. 1998), variations in Eurasian snow cover (Barnett et al. 1988; Robock et al. 2003), and the migration of the Intertropical Convergence Zone (ITCZ) (Philander et al. 1996). Most of the monsoonal precipitation falls on the catchments of the Ganges-Brahmaputra-Meghna rivers (draining most of the Himalayas and the northern part of the Indian subcontinent) resulting in high discharge into the Bay of Bengal (85\% of total drainage) and Andaman Sea (Murata et al. 2008). On the other hand, the westerly cyclonic activity dominates during the winter resulting in minimal precipitation. 
Contrasting atmospheric and continental output govern sea-surface conditions in the Arabian Sea and Bay of Bengal. In the Arabian Sea, the positive net atmospheric divergence flux, i.e., mainly evaporation-precipitation, vary from 3 to $3.5 \mathrm{~mm}$ day $^{-1}$ (Hastenrath and Greischar 1993; Trenberth and Guillemot 1998). This flux can be as high as $20 \mathrm{~mm}$ day $^{-1}$ during June, July and August (JJA) (Peixóto and Oort 1983). The Indus River outflow amounting to $0.006 \mathrm{~Sv}$ $\left(1 \mathrm{~Sv}=10^{6} \mathrm{~m}^{3} \mathrm{~s}^{-1}\right)$ (Perry et al. 1996) is the only continental input into the Arabian Sea. On the other hand, the negative atmospheric net divergence flux, i.e., mainly precipitation is $-1 \mathrm{~mm}$ day $^{-1}$ in the Bay of Bengal (Trenberth and Guillemot 1998). The Ganges-Brahmaputra-Meghna-Irrawaddy discharges $\sim 0.05 \mathrm{~Sv}$ of fresh water resulting from precipitation in their catchments into the Bay of Bengal (Perry et al. 1996). Given that most of the modern precipitation ultimately drains into the Bay of Bengal, the "sink of the Indian summer monsoon," paleo-records from the Bay of Bengal are required for a thorough understanding of past changes of the ISM. Here we present the past changes of the ISM based on proxy records from sea-floor sediments of the Bay of Bengal and Andaman Sea for the last $30 \mathrm{ka}$. From paired oxygen isotope $\left(\delta^{18} \mathrm{O}\right)$ and $\mathrm{Mg} / \mathrm{Ca}$ measurements in the calcite of sea-surface living foraminifera Globigerinoides ruber (white), we reconstruct the sea-surface conditions. The data are placed in a wide, inter-regional context using ice cores, speleothems, marine and lake sediment records to demonstrate coherent changes in the greater Asian monsoon.

$\mathrm{The} \mathrm{Mg} / \mathrm{Ca}$ ratio in $G$. ruber is a commonly used proxy for sea-surface temperature reconstruction. The paired mea- surements of $\delta^{18} \mathrm{O}$ and $\mathrm{Mg} / \mathrm{Ca}$ allowed us to isolate the salinity signal from $\delta^{18} \mathrm{O}$ data, which contains both temperature and salinity-related signals (Lea et al. 2000; Anand et al. 2003; Rashid et al. 2007; Mohtadi et al. 2010). The reconstructed salinity was then used to evaluate whether or not the surface of the Bay of Bengal and Andaman Sea received more or less freshwater from the Ganges-Brahmaputra-Meghna-Irrawaddy (GBMI) outflow and from direct rainfall. Enriched seawater $\delta^{18} \mathrm{O}\left(\delta^{18} \mathrm{O}_{\mathrm{sw}}\right)$ values indicate less dilution of surface water by the reduced GBMI outflow and/or less direct rainfall to the sea surface, indicative of a weaker monsoon and thus a more arid climate in the Indian continental landmass. Conversely, depleted $\delta^{18} \mathrm{O}_{\mathrm{sw}}$ values represent high river outflow and/or more direct rainfall suggesting a stronger ISM and an overall more humid climate. We have used our $\delta^{18} \mathrm{O}_{\mathrm{sw}}$ data to explore whether or not there was a connection between the strength of the ISM and the demise of the Indus Valley Harappan and MohenjoDaro civilizations.

\section{SAMPLES AND METHODS}

Sediment core VM29-19 (R/V Vema, 1971) $\left(14.71^{\circ} \mathrm{N}\right.$, $83.58^{\circ} \mathrm{E}$ ) was retrieved from the Bay of Bengal at 3182 $\mathrm{m}$ water depth, not too close to the continental shelf to be swamped by fine sediments of the GBM discharge (Fig. 1). Core RC12-344 (R/V Conrad, 1969) $\left(12.77^{\circ} \mathrm{N}, 96.07^{\circ} \mathrm{E}\right)$ was retrieved from the Andaman Sea in 1969, presumed to record the changes in the Irrawaddy River discharge, and the isotopic and minor elemental data were described and used

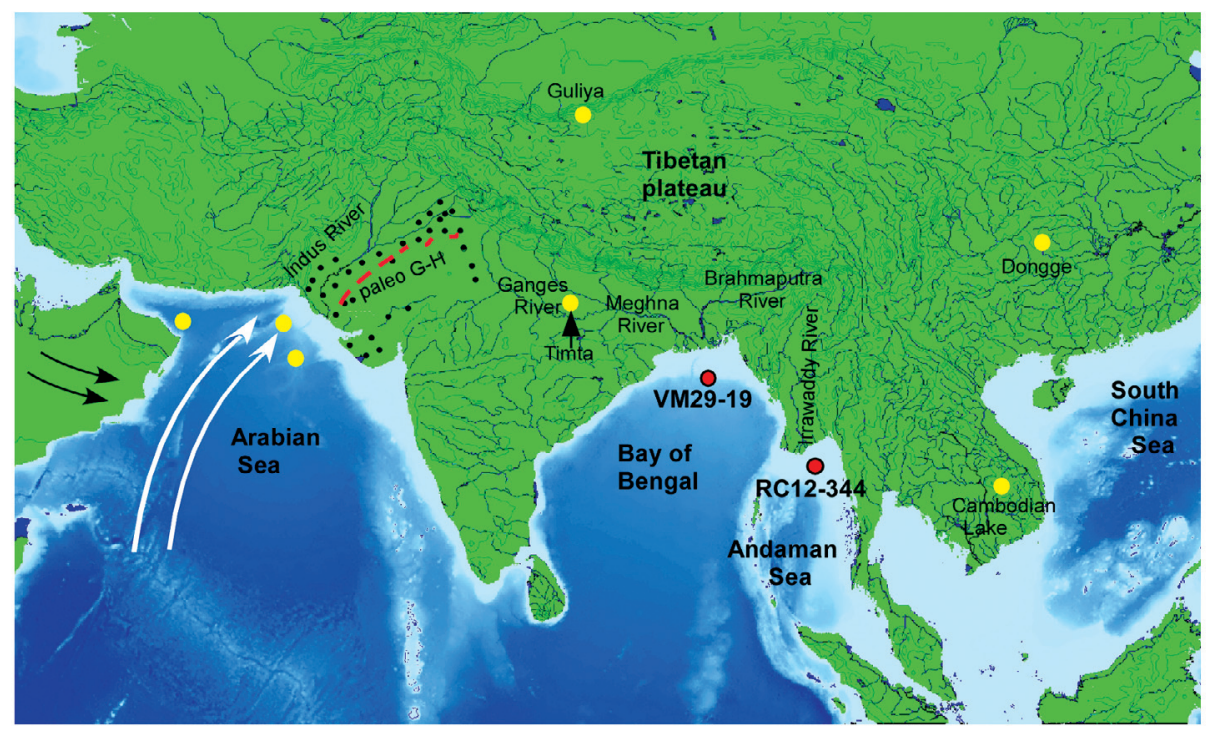

Fig. 1. Map of the study area with locations of paleoclimate records from the Arabian Sea, Bay of Bengal, Andaman Sea, Gangetic Plain, Cambodian Lake, and Dongge cave, and the archaeological sites in the north-western India (black circles). Red dots in the Bay of Bengal and Andaman Sea indicate the location of cores VM29-19 and RC12-344, respectively, used for this study. Long white arrows in the Arabian Sea show the pressure gradient associated with the intensification of the Indian summer monsoon; black arrows indicate the summer pattern of wind from the Arabian Peninsula. Dashed red line is the paleo-Ghaggar-Hakra River (Paleo G-H) and black dots represent the settlements of the Indus Valley Civilizations (Weiss et al. 1993; Madella and Fuller 2006). 
in Rashid et al. (2007). Core VM29-19 was sub-sampled at $2.5 \mathrm{~cm}$ in the Holocene section and 5 to $10 \mathrm{~cm}$ in the glacial interval. Samples were soaked in distilled water overnight and wet-washed using a $63 \mu \mathrm{m}$ sieve. The $>150 \mu \mathrm{m}$ fraction was used to pick planktonic foraminifera for ${ }^{14} \mathrm{C}$ accelerator mass spectrometer $\left({ }^{14} \mathrm{C}\right.$-AMS $)$ dating. ${ }^{14} \mathrm{C}$-AMS dates were determined at the Keck Carbon Cycle Laboratory of University of California at Irvine (Table 1).

\subsection{Chronology of Core VM29-19}

Eight ${ }^{14} \mathrm{C}$-AMS dates (all in stratigraphic order) were acquired from core VM29-19 between 106 and $296 \mathrm{~cm}$. The ${ }^{14} \mathrm{C}$-AMS dates were calibrated to calendar years before the present (1950) using the CALIB6.0.1 online software program (Reimer et al. 2009) where MARINE09 data sets were used. A standard ocean reservoir correction of 400 years was applied by an algorithm used by the calibration program. Residual reservoir ages $(\Delta R)$ of -78 and -2 yrs were used for the Bay of Bengal and Andaman Sea, respectively, following the findings of Southon et al. (2002). The calibrated ages adopted with the highest probability are reported in the Table 1. The age of $1.34 \mathrm{ka}$ was obtained for the core top by extrapolation (Fig. 2). Sedimentation rates, calculated by assuming constant sedimentation between the dating points, vary from $22 \mathrm{~cm} \mathrm{kyr}^{-1}$ for the Holocene to $10.6 \mathrm{~cm} \mathrm{kyr}^{-1}$ in the last glacial.

\subsection{Stable Isotopic Analysis}

Oxygen and carbon stable isotopes were determined in the handpicked planktonic foraminifera G. ruber from the 250 to $355 \mu \mathrm{m}$ size. Analyzed subsamples had masses of $\sim 85-105 \mu \mathrm{g}$, but as little as $\sim 60 \mu \mathrm{g}$. Stable-isotope compositions were determined using a Finnigan Delta IV Plus light stable-isotope ratio mass spectrometer (SIRMS) coupled to an automated carbonate preparation device (Kiel III Device) at the Stable Isotope Biogeochemistry Laboratory of The Ohio State University. Samples were acidified under vacuum with $100 \%$ ortho-phosphoric acid, the resulting $\mathrm{CO}_{2}$ was cryogenically purified, and delivered to the mass spectrometer. Approximately $10 \%$ of all samples were run in duplicate and showed reproducible results. The standard deviation of repeated measurements of an internal standard was $\pm 0.023 \%$ o for $\delta^{13} \mathrm{C}$ and $\pm 0.045 \%$ o for $\delta^{18} \mathrm{O}$. The overall analytical reproducibility, as determined from replicate measurements on the standard material (NBS19 ), is routinely better than $\pm 0.05 \%$ o $( \pm 1 \sigma)$ for both $\delta^{18} \mathrm{O}$ and $\delta^{13} \mathrm{C}$.

\subsection{Mg/Ca Analysis and SST Estimation}

Before analyzing foraminiferal samples for minor elemental concentration, specimens were cleaned for contaminants such as clays, organic matter, and metal overgrowths. A detailed description of the cleaning procedure is given in Rashid et al. (2007), but here we provide a brief description. Approximately twenty G. ruber tests from the 250 to $355 \mu \mathrm{m}$ size fraction were gently crushed under a binocular microscope, but care was taken not to pulverize broken shell fragments (Rashid and Boyle 2004). Crushed samples were cleaned according to the Boyle and Keigwin (1985/86) cleaning protocol, but changing the order to mechanical (multiple sonication before treating samples by trace metal grade methanol), then reductive [using hydrazine in citric acid and $\mathrm{NH}_{4}(\mathrm{OH})$ buffer], and oxidative cleaning (using $\mathrm{NaOH}$ and $\left.\mathrm{H}_{2} \mathrm{O}_{2}\right)$ and final polishing with weak $(0.001 \mathrm{M})$ nitric acid. Samples were dissolved by 0.2 normal nitric acid and a $300 \mu \mathrm{l}$ of aliquot was removed and diluted by 0.2 normal nitric acid to make up to $\sim 1 \mathrm{ml}$ solution for analyses.

Table 1. ${ }^{14} \mathrm{C}$-AMS dates used for core VM29-19.

\begin{tabular}{|c|c|c|c|c|c|}
\hline & Lab ID & Depth $[\mathrm{cm}]$ & Species used for dating & Raw ${ }^{14} \mathrm{C}$-AMS dates & Calibrated age $(\mathrm{Yr} \mathrm{BP}) * 1 \sigma$ range \\
\hline 1 & UCI-16840 & $106-107$ & Mixed planktonics & $4690 \pm 15$ & $4860-4937$ \\
\hline 2 & UCI-53927 & $140-141$ & Mixed planktonics & $7740 \pm 35$ & $8168-8266$ \\
\hline 3 & UCI-16841 & $160-161$ & Mixed planktonics & $10225 \pm 20$ & $11187-11222$ \\
\hline 4 & UCI-53928 & $190-191$ & Mixed planktonics & $12445 \pm 40$ & $13819-13950$ \\
\hline 5 & UCI-52929 & $204-205$ & Mixed planktonics & $15130 \pm 45$ & $17768-18019$ \\
\hline 6 & UCI-52930 & $221-222$ & Mixed planktonics & $17130 \pm 60$ & $19820-20062$ \\
\hline 7 & UCI-52931 & $255-256$ & Mixed planktonics & $20580 \pm 80$ & $23938-24254$ \\
\hline 8 & UCI-52932 & $295-296$ & Mixed planktonics & $23150 \pm 100$ & $27497-27844$ \\
\hline
\end{tabular}

* All ${ }^{14} C$-AMS dates were determined on the mixed planktonic foraminifers which were converted to calendar age (BP) by using CALIB 6.0 .1 (Reimer et al. 2009) calibration program (see text). 
(a)
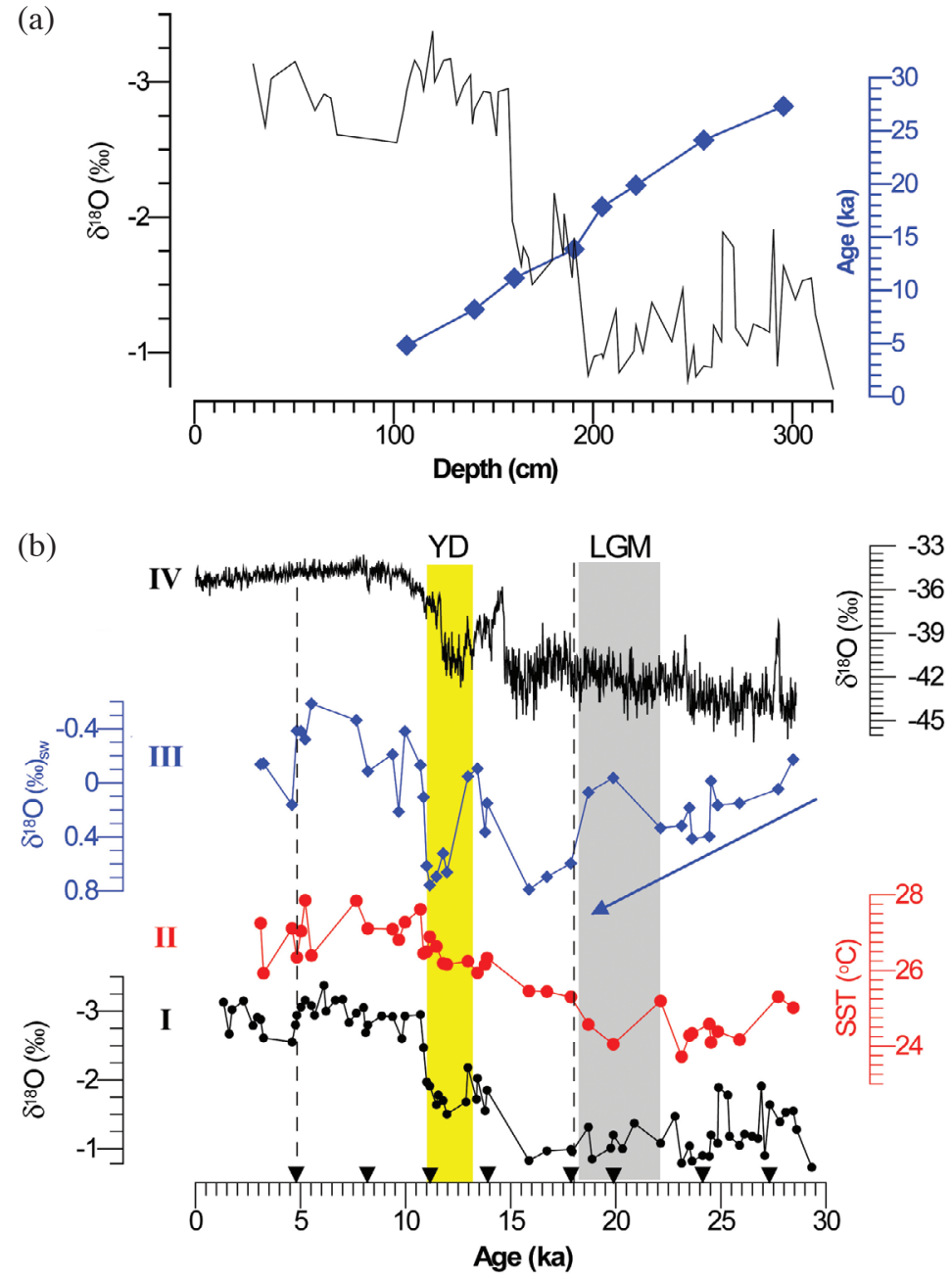

Fig. 2. (a) Age (ka; kyr BP) versus core depth plot with the $\delta^{18} \mathrm{O}$ values in the Globigerinoides ruber (white) in the Bay of Bengal core VM29-19, retrieved from the western shelf at $3182 \mathrm{~m}$ water depth. Radiocarbon ages were converted to calendar years (before present) by using the calibration program CALIB 6.0.1 (Reimer et al. 2009; see text for details). (b) Downcore data from core VM29-19 based on G. ruber from the 250 to $355 \mu$ m size fraction: (I) $\delta^{18} \mathrm{O}$; (II) sea-surface temperature (SST) estimates derived from $\mathrm{Mg} / \mathrm{Ca}$ using the calibration equation of Anand et al. (2003); (III) seawater $\delta^{18} \mathrm{O}\left(\delta^{18} \mathrm{O}_{\text {sw }}\right)$ derived from $\delta^{18} \mathrm{O}-\mathrm{Mg} / \mathrm{Ca}$ by using the paleotemperature equation of Mulitza et al. (2003); (IV) $\delta^{18} \mathrm{O}$ from the Greenland ice core according to the new Greenland ice core chronology (GICC05) (Rasmussen et al. 2006) are plotted to demonstrate coherency with the Northern Hemisphere major climate transitions. Arrows on the age scale indicate ${ }^{14} \mathrm{C}$-AMS dates (all in stratigraphic order) used to constrain the age model. The blue arrow indicates the progressive enrichment of seawater $\delta^{18} \mathrm{O}$. YD = Younger Dryas; LGM = Last Glacial Maximum.

Aliquots were analyzed on a Perkin Elmer 4300 dual view inductively coupled plasma-optical emission spectrometer (ICP-OES) at the College of Marine Science, University of South Florida. $\mathrm{Mg}, \mathrm{Ca}$, and $\mathrm{Sr}$ were the target elements for quantitative purpose, whereas the $\mathrm{Al}, \mathrm{Fe}$, and Mn were routinely measured simultaneously to evaluate the cleaning protocol. In some samples $\mathrm{Mn} / \mathrm{Ca}$ ratios are high, however, no consistent relationship between $\mathrm{Mn} / \mathrm{Ca}$ and $\mathrm{Mg} / \mathrm{Ca}$ ratios were found suggesting that the slight increase of $\mathrm{Mn} / \mathrm{Ca}$ had no effect on the $\mathrm{Mg} / \mathrm{Ca}$. Results indicate an analytical precision for $\mathrm{Mg} / \mathrm{Ca}$ of $\leq 0.4 \%$ root-mean standard deviation $(1 \sigma)$. The average precision of all data based on duplicates or triplicates is \pm 0.15 for $\mathrm{Mg} / \mathrm{Ca}$, which corresponds to $\pm 0.4^{\circ} \mathrm{C}$.

SST was estimated from $\mathrm{Mg} / \mathrm{Ca}$ ratios using a speciesspecific equation developed from North Atlantic sediment- trap and core-top calibrations: $\mathrm{Mg} / \mathrm{Ca}=0.38 \mathrm{xe}^{(0.09 \times \mathrm{xST})}$, where the $\mathrm{Mg} / \mathrm{Ca}$ concentration ratio in the foraminiferal test is in $\mathrm{mmol} / \mathrm{mol}$ and the SST is in ${ }^{\circ} \mathrm{C}$ (Elderfield and Ganssen 2000; Anand et al. 2003). We used G. ruber-specific calibration of Mulitza et al. $(2003)\left[\delta^{18} \mathrm{O}_{\mathrm{sw}}=\left(\mathrm{T}_{\mathrm{Mg} / \mathrm{Ca}}-14.2\right) / 4.44\right.$ $\left.+\delta^{18} \mathrm{O}\right]$ to calculate $\delta^{18} \mathrm{O}_{\text {sw }}$ and converted them to Vienna Standard Mean Ocean Water (VSMOW) by adding $0.27 \%$ to the estimated $\delta^{18} \mathrm{O}_{\mathrm{sw}}$ values (Hut 1987). Effects of global ice volume change were corrected using a sea-level record from Fairbanks (1989) to separate residual $\delta^{18} \mathrm{O}_{\mathrm{sw}}$ for the Bay of Bengal. A relationship between the $\delta^{18} \mathrm{O}_{\mathrm{sw}}$ and sealevel of $0.0083 \% \mathrm{~m}^{-1}$ sea-level (Adkins et al. 2002) was also applied.

Modern depth of the lysocline in the Bay of Bengal lies near $2600 \mathrm{~m}$ and deepens to about $3800 \mathrm{~m}$ in the eastern 
equatorial Indian Ocean (Chen et al. 1995). We have used the foraminiferal weight (Rashid et al. 2007), instrumental Ca-signal, and any signature of shell mass loss under the microscope to assess dissolution (Saher et al. 2007). We have not encountered any dissolution event.

\section{RESULTS}

The top $320.5 \mathrm{~cm}$ of core VM29-19 covers the last $29.3 \mathrm{ka}$ of paleoclimate record in the Bay of Bengal. $G$. ruber $\delta^{18} \mathrm{O}$ shows a $\sim 1.8 \%$ change between the Holocene and last glacial periods. Two depleted $\delta^{18} \mathrm{O}$ peaks centered at 267 and $290 \mathrm{~cm}$ correspond to the ages of 25 and $27 \mathrm{ka}$, respectively (Fig. 2) could be equivalent to the DansgaardOeschger events of the North Atlantic (Bond et al. 1993; Rashid and Boyle 2008). However, this tentative correlation needs to be constrained by increasing the resolution of $\delta^{18} \mathrm{O}$ data and additional ${ }^{14} \mathrm{C}$-AMS dates at the base of these depleted $\delta^{18} \mathrm{O}$ excursions. The interval encompassing the Bølling-Allerød (B/A) from 191 to $201 \mathrm{~cm}$ does not contain enough foraminifers, so this transition could not be clearly determined. The Younger Dryas (YD) is characterized by $\sim 1.5 \%$ o enriched $\delta^{18} \mathrm{O}$ values compared to the Holocene. Depleted $\delta^{18} \mathrm{O}$ values characterize the early Holocene interval, however, a sharp enrichment of $0.5 \%$ occurs at $\sim 4.8 \mathrm{ka}$ consistent with the $\delta^{18} \mathrm{O}$ values in core RC12-344 from the Andaman Sea (Rashid et al. 2007) (Fig. 3).

The estimated SSTs were $\sim 2.8^{\circ} \mathrm{C}$ colder during the last glacial maximum (LGM) compared to the Holocene in the Bay of Bengal (Fig. 2). Lack of G. ruber in sediments near the core top prevented us from reconstructing SSTs for the last ca. $3.1 \mathrm{ka}$. In addition, there are no core top $\mathrm{Mg}$ / $\mathrm{Ca}$ ratios available from the Bay of Bengal at present to evaluate the modern SST estimation by this proxy. Depleted $\delta^{18} \mathrm{O}_{\text {sw }}$ values between the 18.2 and $22 \mathrm{ka}$, and the most depleted $\delta^{18} \mathrm{O}_{\mathrm{sw}}$ values were observed from 10.6 to $5 \mathrm{ka}$, approximately correspond to the LGM and the early Holocene periods, respectively. The interval between 14.8 and $18 \mathrm{ka}$ and the YD show enriched values in comparison to the early Holocene by $\sim 1 \%$ and the $\mathrm{B} / \mathrm{A}$ period has the depleted $\delta^{18} \mathrm{O}_{\mathrm{sw}}$ values (Fig. 2).

\section{DISCUSSION}

\subsection{Deglacial Climate in the Bay of Bengal}

Detailed paleoclimate records of shorter or longer time-scales from the Bay of Bengal are rare (Kudrass et al. 2001). Our $\delta^{18} \mathrm{O}$ data in G. ruber show a $\sim 1.8 \%$ difference between the late glacial and the Holocene (Fig. 2). A similar magnitude of $\delta^{18} \mathrm{O}$ change has also been reported from the Arabian Sea (Schmiedl et al. 2006; Saher et al. 2007; Anand et al. 2008) and the Andaman Sea (Duplessy 1982; Rashid et al. 2007).

A $\sim 2.8^{\circ} \mathrm{C}$ cooler SST during the LGM in the Bay of
Bengal (Fig. 2) is consistent with a similar magnitude of cooling reported for the tropical Indian Ocean (Naidu and Malmgren 1995; Sonzogni et al. 1998; Rashid et al. 2006), but is considerably larger than the $1^{\circ} \mathrm{C} \mathrm{SST}$ cooling estimated by the CLIMAP (1981) and Cullen (1981) using the foraminiferal assemblage transfer function and foraminiferal $\delta^{18} \mathrm{O}$ based techniques from Duplessy (1982), respectively. Kudrass et al. (2001) reconstructed millennial-scale SST and salinity changes from the lower Bengal slope at $1253 \mathrm{~m}$ water depth. These authors used the alkenone-extracted SST estimates of Sonzogni et al. (1998) from the tropical Indian Ocean to calculate salinity. As a result, a $2^{\circ} \mathrm{C}$ cooler SST was reported for the early Holocene compared to the late and mid Holocene. Such a cooling in the early Holocene is in stark contrast to all other climate records of greater Asian monsoon (Barrows and Juggins 2005; Saher et al. 2007; Anand et al. 2008; Mohtadi et al. 2010) including our results (Andaman Sea, Rashid et al. 2007; and this contribution). We were unable to analyze the core top due to the lack of $G$. ruber in sediment younger than ca. $3.1 \mathrm{ka}$ and the physical lack of sediment younger than ca. $1.3 \mathrm{ka}$, which was possibly lost during the coring process. However, our reconstructed SST of $27.3^{\circ} \mathrm{C}$ at $3.1 \mathrm{ka}$ (Fig. 2) approximately matches the modern annual mean SST in this region (Levitus and Boyer 1994; Barrows and Juggins 2005).

Seawater $\delta^{18} \mathrm{O}$ values show a progressive enrichment between 30 and $15.8 \mathrm{ka}$ with the depleted $\delta^{18} \mathrm{O}_{\mathrm{sw}}$ values truncating the trend between 22.3 and $18.2 \mathrm{ka}$ (Fig. 2). The most enriched $\delta^{18} \mathrm{O}_{\mathrm{sw}}$ values occur between 18.2 and $15.6 \mathrm{ka}$ and in the YD. These enriched $\delta^{18} \mathrm{O}_{\mathrm{sw}}$ values suggest that the ISM was the weakest during these periods and the climate was drier inducing less GBM outflow and/or less direct rainfall. On the other hand, the depleted $\delta^{18} \mathrm{O}_{\mathrm{sw}}$ values from 22.2 to $18.2 \mathrm{ka}$ (Fig. 2) suggest a stronger ISM and more GBM outflow and/or direct rainfall. These results are important for testing the sensitivity of monsoonal precipitation during the reorganized glacial boundary conditions and atmospheric circulation (Broccoli et al. 2006; Levermann et al. 2009). The interval encompassing the transition period between the last glacial and B/A climate could not be determined due to the lack of foraminifera which may be related to a significant GMB outflow and supply of fine sediments to the core site VM29-19. The depleted $\delta^{18} \mathrm{O}_{\mathrm{sw}}$ values suggest a humid climate and freshening in the Bay of Bengal during the B/A period (Fig. 2).

\subsection{Holocene Climate in the Bay of Bengal}

The most depleted $\delta^{18} \mathrm{O}_{\mathrm{sw}}$ values were found in the early Holocene, which suggests that it was the wettest period with the strongest ISM resulting in a drastic precipitation increase in the catchments of the GBM rivers and/or more direct precipitation in the Bay of Bengal. These results are consistent with other Holocene records in and around the 
Arabian Sea (Fleitmann et al. 2003; Gupta et al. 2005) and Andaman Sea (Rashid et al. 2007).

Our Bay of Bengal records do not cover the climate history of the last $3.1 \mathrm{ka}$ due to the paucity of foraminifera in samples in this interval. In addition, lack of enough foraminifera prevented us from carrying out $\mathrm{Mg} / \mathrm{Ca}$ analysis on all samples (hence a relatively fewer $\delta^{18} \mathrm{O}_{\mathrm{sw}}$ data points compared to the G. ruber $\delta^{18} \mathrm{O}$ ). Nevertheless, the enriched $\delta^{18} \mathrm{O}_{\mathrm{sw}}$ values between 4.8 and $3.1 \mathrm{ka}$ follow the trend of enriched $\delta^{18} \mathrm{O}_{\mathrm{sw}}$ values between 4.8 and $1.4 \mathrm{ka}$ in the Andaman Sea record (Rashid et al. 2007) (Fig. 3). These enriched $\delta^{18} \mathrm{O}_{\mathrm{sw}}$ values indicate a drier climate at both basins. This suggests less precipitation and reduction in GBM outflow to the Bay of Bengal in the late Holocene. Modern observations show $\delta^{18} \mathrm{O}_{\mathrm{sw}}$ values between 0 and $-2 \%$ from equator to the northern Bay of Bengal during January and February, i.e., during the winter monsoon with low precipitation and runoff (Delaygue et al. 2001). We speculate that if the measurements were conducted during the summer monsoon, these values would be much depleted as predicted by oceanatmospheric general circulation modeling (Delaygue et al. 2001; Kageyama et al. 2009).

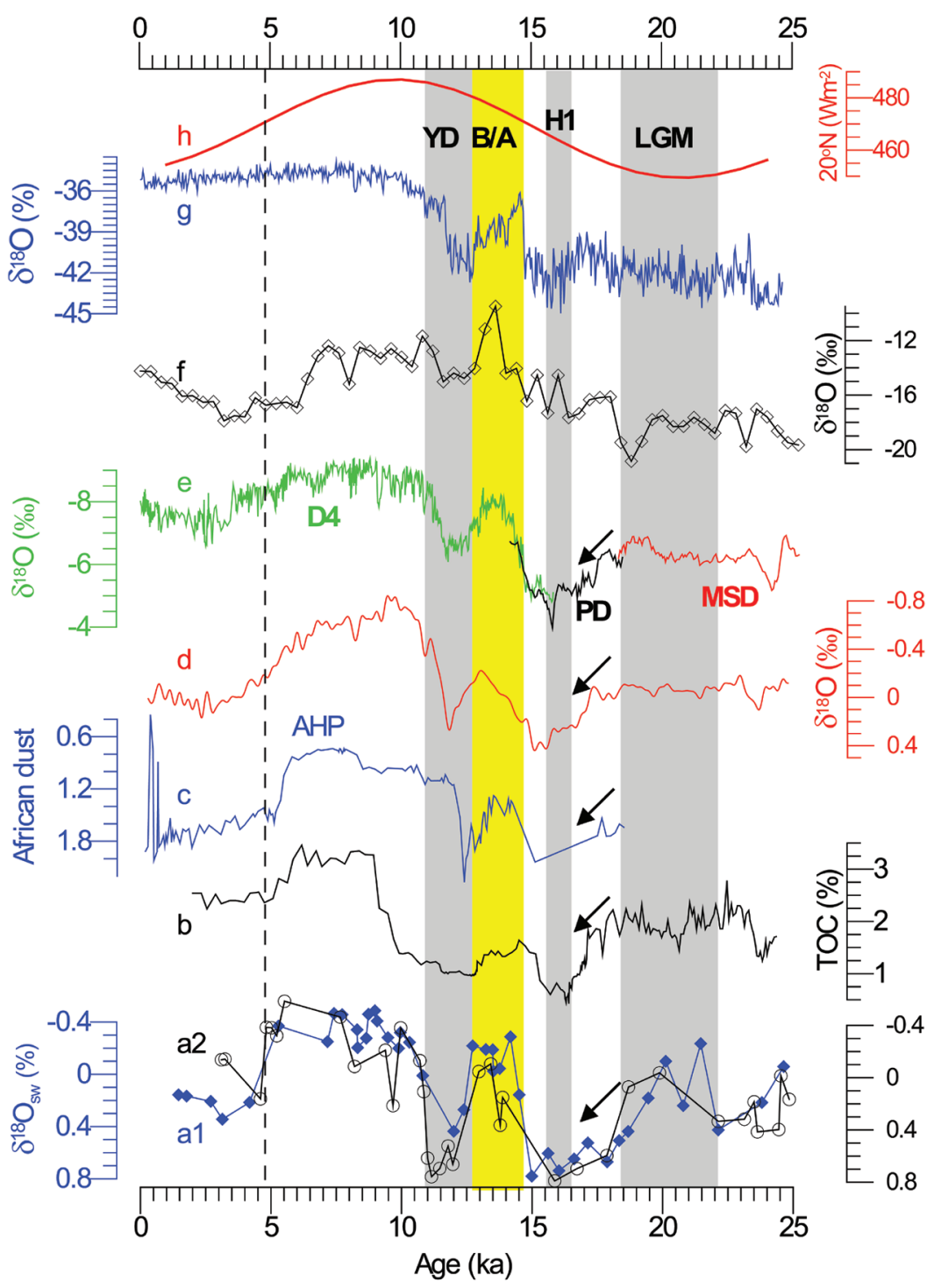

Fig. 3. Proxy records of the Indian and Asian monsoons and Greenland and Tibetan ice cores data plotted using their independent age models. From the bottom to top: $\delta^{18} \mathrm{O}_{\mathrm{sw}}$ from (a1) the Andaman Sea (blue diamonds) (Rashid et al. 2007) and (a2) Bay of Bengal (unfilled circles) from cores RC12-344 (Rashid et al. 2007) and VM29-19 (this study), respectively; (b) Marine biological productivity (total organic carbon) records from the Arabian Sea (Schulz et al. 1998); (c) African mineral dust flux from the eastern tropical Atlantic Ocean off Cape Blanc (Mauritania) (note scale inverted) (de Menocal et al. 2000); (d) $\delta^{18} \mathrm{O}_{\text {atm }}$ (atmospheric molecular oxygen; a proxy for the planetary photosynthesis and respiration) (Severinghaus et al. 2009); (e) Chinese $\delta^{18} \mathrm{O}$ speleothems data from the Hulu and Dongge caves (Wang et al. 2005, 2008); $\delta^{18} \mathrm{O}$ data from (f) Guliya (Thompson et al. 2002, 2006) and (g) Greenland ice cores (Rasmussen et al. 2006), and (h) the summer insolation at 20 N (Laskar 1990). AHP: African Humid Period; B/A = Bølling-Allerød; and H1 = Heinrich event 1. 
Paradigm of a stable Holocene climate mainly stemmed from the monotonous nature of the $\delta^{18} \mathrm{O}$ Greenland and Antarctic ice cores (Fig. 4). However, this paradigm has been challenged in the last five years by evidence from the presumably stable tropical regions that show dramatic, submillennial to millennial-scale hydrologic and thermal variability irrespective of altitude (Thompson et al. 2002, 2006; Wang et al. 2005, 2008). In Fig. 4, we illustrate the variability in the high Tibetan Plateau $\delta^{18} \mathrm{O}$ records that show dramatic changes, consistent with the ice core records from Kilimanjaro and the hydrological variability in the Bay of Bengal and Andaman Sea, whereas the Greenland climate remained stable. We hypothesize that once the global climate reaches a certain threshold or mean state the polar climate becomes insular compared to changes in the tropics. Whether such isolation is mechanistically plausible can be tested by high resolution climate modeling.

\subsection{The Bay of Bengal Monsoon and the Regional Climate Connections}

Our Indian monsoon proxy records from the Bay of Bengal and Andaman Sea are plotted with other highly resolved climate records from the African and Asian mon-

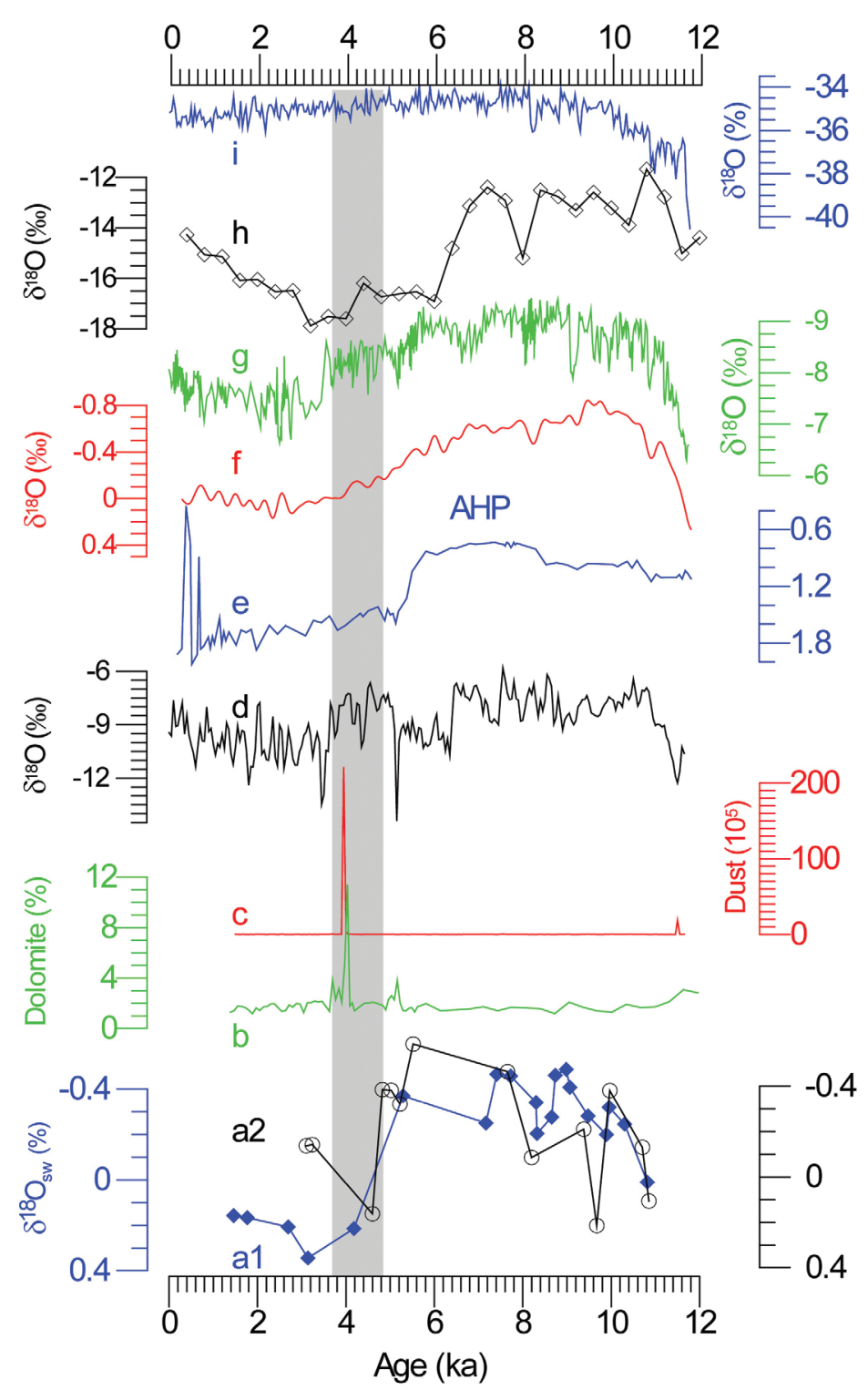

Fig. 4. Holocene climate records from the greater Asian region, plotted in comparison with Greenland, Tibetan, and Kilimanjaro ice-core data according to their independent age models. (a1) - (a2) Andaman Sea (Rashid et al. 2007) and Bay of Bengal seawater $\delta^{18} \mathrm{O}$ values (this study), (b) Gulf of Oman dolomite concentration (Cullen et al. 2000), (c) - (d) Kilimanjaro ice core (NIF3) dust flux and $\delta^{18} \mathrm{O}_{\text {ice, }}$ (Thompson et al. 1997, 2006), (e) African dust flux (de Menocal et al. 2000); (f) - (i) $\delta^{18} \mathrm{O}$ records from the atmospheric molecular oxygen (Severinghaus et al. 2009), Chinese (Dongge) cave (Wang et al. 2005), Tibetan (Guliya) ice core (Thompson et al. 1997, 2006) and Greenland ice cores (Rasmussen et al. 2006). The grey bar shows the major climate transition between 5.2 and $4.2 \mathrm{ka}$. 
soons to demonstrate the changes in the tropical climate (Fig. 3). The Bay of Bengal SST data show a continuous, gradual warming starting at $\sim 18.8$ ka consistent with the seasurface warming from the Sulu Sea (Rosenthal et al. 2003), Makassar Strait (Visser et al. 2003) and the western Pacific Warm Pool (Lea et al. 2000; Stott et al. 2002). Within dating uncertainties, this warming could be tied to the first rise in atmospheric carbon dioxide (Monnin et al. 2001). The wet Indian monsoon interval between 22.2 and $18.2 \mathrm{ka}$ was accompanied by depleted $\delta^{18} \mathrm{O}_{\mathrm{sw}}$ values and atmospheric molecular oxygen $\left(\delta^{18} \mathrm{O}_{\text {atm }}\right)$ higher than the late Holocene (Fig. 3d) (Severinghaus et al. 2009). The weakest ISM between 18.2 and $14.8 \mathrm{ka}$ is consistent with the weak Asian monsoon resulting in the lowest precipitation in China as inferred from the Hulu, Donggee and Sanbao speleothem records (Wang et al. 2005, 2008) as well as the weakest Arabian Sea biological productivity (Fig. 3b) (Schulz et al. 1998) and Arabian Sea monsoon (Saher et al. 2007; Anand et al. 2008). This weaker monsoon is also consistent with a higher supply of African mineral dust (stronger windblown dust) from northwest Africa to the neighboring eastern tropical Atlantic Ocean (Fig. 3c) (de Menocal et al. 2000; Mulitza et al. 2008) for the same period. Recently, Severinghaus et al. (2009) equated this weaker monsoon interval with the enriched $\delta^{18} \mathrm{O}_{\text {atm }}$ which is mainly governed by the strength of the Asian and North African monsoons. There are leads and lags in the records resulting from the divergence in age models; however, Heinrich event 1 seems to be nested within this weakest monsoon period.

The proxy records for the YD show weaker Indian and Asian monsoons and a dry north Africa as revealed from the high dust flux (a narrower high dust peak) suggesting a strong continental wind input (Fig. 3c) (de Menocal et al. 2000; Mulitza et al. 2008). Proxy records from Guliya ice core (Fig. 3f) and depleted $\delta^{18} \mathrm{O}_{\text {atm }}$ suggest that the Tibetan plateau climate and the global turnover of atmospheric oxygen also deteriorated at this time. Towards the end of the YD in the Andaman Sea, G. ruber $\delta^{18} \mathrm{O}$ values show a feature similar to the $\delta^{18} \mathrm{O}$ records of Hulu Cave. A similar but subdued $\delta^{18} \mathrm{O}$ pattern has also been reported from the South China Sea (Steinke et al. 2006). The apparent mismatch in duration of these proxy records could result from the discrepancies in age models; alternatively, it could mean that some of the tropical proxies responded earlier to an "unknown" forcing. The B/A and YD periods of freshening and dry episodes of the Indian monsoon can also be correlated to the freshening and dry events in the western Equatorial Pacific, South China, and Sulu seas (Kienast et al. 2001; Stott et al. 2002; Steinke et al. 2008). These findings suggest that the ISM and the greater Asian monsoon system have undergone synchronous hydrological and climate changes.

The most depleted early Holocene $\delta^{18} \mathrm{O}_{\mathrm{sw}}$ values suggest a wetter condition, and by extension, we infer this period to be associated with the strongest ISM. Both the Asian monsoon and African Humid Period (AHP) records suggest more precipitation in the Asian landmass, warmer climate in the Tibetan Plateau, and less supply of African mineral dust, consistent with our results (Fig. 3). An increase in continental wetness has also been reported from lake records across the Sahel region of Africa (van Campo et al. 1982; Lamb et al. 1995; Gasse and Roberts 2005) and northwestern India (Morrill et al. 2003; Sharma et al. 2004; Sinha et al. 2005), and soil formation in China (Porter and An 1995; Han et al. 2010). The Arabian Sea biological productivity did not reach its Holocene maximum until after $9.2 \mathrm{ka}$ (Schulz et al. 1998) suggesting an enigmatically weaker upwelling interval between 11.6 and $9.2 \mathrm{ka}$. However, the highest total organic carbon (TOC) concentrations were found between 9 and 5.8 ka (Fig. 3b) suggesting a stronger biological productivity for this interval.

The late Holocene Bay of Bengal and Andaman Sea enriched $\delta^{18} \mathrm{O}_{\text {sw }}$ values suggest a dry condition and hence a weaker ISM. Our records are similar to the speleothem records of the Gupteshar and Dandak caves of eastern India (Yadava and Ramesh 2005). These authors also inferred a weaker ISM for the last $4 \mathrm{ka}$. A drastic decrease in the ISM and hence less precipitation were also inferred from the desertification in northern India (Swain et al. 1983), drops in lake levels in Africa and the Tibetan Plateau (Lamb et al. 1995; Morrill et al. 2003; Gasse and Roberts 2005) and windiness in the Arabian peninsula (Overpeck et al. 1996). From an ultra-high resolution study of Chinese speleothems, a reduction in the Asian monsoon has also been reconstructed by Wang et al. $(2005,2008)$.

Solar insolation has often been invoked to explain the transition from the glacial to Holocene climate. The earth solar insolation during the LGM was within $1 \mathrm{~W} \mathrm{~m}^{-2}$ of present day values and carbon dioxide concentration was 80 ppm lower than today (Lasker 1990; Monnin et al. 2001). It is the combination of these two factors, in conjunction with the greater ice volume that was responsible for decreasing global net radiation relative to today. However, change in the summer (July) solar insolation was one of the mechanisms which could have altered the tropical monsoon resulting in cooler and drier conditions in the Himalayan and Tibetan region and reducing the land-sea pressure gradient (Kutzback and Street-Perrott 1985). As a result, the Indian subcontinent received less precipitation and direct precipitation in the GBMI catchments as demonstrated by the enriched $\delta^{18} \mathrm{O}_{\mathrm{sw}}$ values. On the other hand, the records of abrupt events such as the $\mathrm{YD}, \mathrm{B} / \mathrm{A}$ etc. require additional forcing as discussed in the subsequent paragraph.

Correlation of our Bay of Bengal and Andaman Sea $\delta^{18} \mathrm{O}_{\mathrm{sw}}$ data with cave, marine, lake, and ice cores records provides a link to various components of the Northern Hemisphere climate system (Fleitmann et al. 2003; Wang et al. 2005, 2008). A possible mechanistic link that can explain this relationship for the abrupt climate events comes from 
modern observational data as synthesized by Robock et al. (2003) as well as a modeling study of Barnett et al. (1988). The authors suggested that warm, low-snow winters in Eurasia will be accompanied by anomalously strong Asian monsoons the following summer. Apparently, the warmth propagates eastward to central Asia increasing the land-sea temperature contrast, thus intensifying low pressure and precipitation associated with the monsoon (Webster et al. 1998; Cane 2010). The freshwater release in the North Atlantic preconditions the formation of sea ice by sea-surface cooling and thus extends the regional sea-ice cover. As a result, the expanded sea ice reduces the ocean-atmosphere heat exchange to the prevailing westerlies and, hence, induces more cooling in the continental Europe. Furthermore, modeling studies suggest a displacement of the ITCZ farther south associated with the amount of freshwater (Broccoli et al. 2006). At any rate, we suggest a combination of mechanisms could have acted over the longer timescales and was even more influential during the large climate oscillations of the $\mathrm{B} / \mathrm{A}$ and $\mathrm{YD}$ periods. Identification of these events in the Bay of Bengal and Andaman Sea provides support for the connectivity of the North Atlantic climate and ISM.

\subsection{Late Holocene Indian Monsoon and the Demise of the Indus Valley Civilizations}

When most of the agricultural expansion occurred within the Indus Valley, the Harappan and Mohenjo-Daro civilizations were at their peak about 4.6 to $4.5 \mathrm{ka}$. These civilizations began to decline at around 4 to $3.9 \mathrm{ka}$ leaving completely abandoned settlements between 3.6 and $3.4 \mathrm{ka}$ (Weiss et al. 1993; Kenoyer 1998). A favored hypothesis explaining the decline of the Indus Valley civilizations is that inferred changes in the course of the then Ghaggar-Hakra River, the former dried out Ghaggar-Hakra river, forced the dispersion of settlements (Fig. 1) (Madella and Fuller 2006). The link between the climate change or, more precisely, changes in the ISM strength and the disappearance of the Indus Valley Civilizations has rarely been explored or the role of the ISM has been viewed as secondary factor (Possehl 2002; Madella and Fuller 2006).

The sharp change in the Andaman Sea and Bay of Bengal $\delta^{18} \mathrm{O}_{\mathrm{sw}}$ values were found from 5.3 to 4.2 and 4.8 to $4.6 \mathrm{ka}$ (Fig. 4), respectively, suggests an abrupt GBMI outflow reduction and/or less direct rainfall, and hence a weak ISM. Our $\delta^{18} \mathrm{O}_{\mathrm{sw}}$ records are too coarse to resolve the precise onset date for this weak ISM event; the age models for the Bay of Bengal and Andaman Sea records suggest the timing between 4.8 and $4.2 \mathrm{ka}$. This date approximately coincides with the demise of the African Humid Period, a sharp decline in the Arabian Sea productivity (Schulz et al. 1998), and an abrupt increase of dust in Guliya ice core in Tibetan Plateau (Thompson et al. 1997, 2006) suggesting the onset of a dry and windy climate (Fig. 4). A sharp increase in dolomite in the Gulf of Oman at 4.15 ka (Fig. 4) indicating a windy climate has been correlated to the demise of the Akkadian empire (Cullen et al. 2000), consistent with the high salinity event $\sim 4.2$ ka reconstructed from the marine sediments of northern Red Sea (Arz et al. 2006). The beginning of the arid period at $\sim 4.5 \mathrm{ka}$ and its intensification at $\sim 3.5 \mathrm{ka}$ is also found in the pollen records from the Higher Garhwal Himalayas and northwestern India (Phadtare 2000). A shift toward an arid phase at $4.2 \mathrm{ka}$ was also found in the vegetation history from the lake records of Rajasthan. Desiccation of river channels in the Gangetic plain (Sharma et al. 2004) and reduction in Cambodian lake levels (Maxwell 2001) also occurred between 5 and $4 \mathrm{ka}$. Thus, it appears that the abrupt dry event at $\sim 4.2$ ka ushered the step-wise weakening of the Asian monsoon.

Asian monsoon records from the Dongge caves show a drastic reduction in precipitation at around the same time, although there are some mismatches in the age models between different records. In the African Kilimanjaro ice core, Thompson et al. (2006) showed that an abrupt enrichment of $\delta^{18} \mathrm{O}$ at $5.2 \mathrm{ka}$ was followed by a gradual decrease and a major drought recorded in the dust concentration at $4.2 \mathrm{ka}$ suggesting that the tropical hydrological cycle was also modified at this time (Fig. 4). At the same time, the planktonic foraminiferal $\delta^{18} \mathrm{O}$ data from the Makran margin off the coast of Pakistan show just a slightly enriched $\delta^{18} \mathrm{O}$ signal suggesting only a minor reduction of the Indus River outflow at $4.2 \mathrm{ka}$ (Staubwasser et al. 2003). In summary, these independent proxy records suggest that the African and Indo-Asian monsoon experienced coherent rapid hydrological changes during the late Holocene period including a dramatic decrease in the ISM at $\sim 4.5 \mathrm{ka}$. The weakening of the ISM starting at $\sim 5 \mathrm{ka}$ and becoming severe at $4.2 \mathrm{ka}$ has been considered as a factor in the Indus Valley civilization decline but its impact has not been fully appreciated (Possehl 2002; Madella and Fuller 2006). The lukewarm response to this gradual ISM weakening hypothesis presumably results from the lack of robust paleoclimatic evidence for the reduction of Indus outflow in the Arabian Sea and lakes of Rajasthan. Most of the archaeological excavations were conducted along the former Ghaggar-Hakra and the Indus Rivers to understand the changes in the Indus Valley Civilizations, whereas, paleoclimatic reconstructions have been focused on sites proximal to these Civilizations such as the Makran margin off the coast of Pakistan (Staubwasser et al. 2003).

Most precipitation over the Indian landmass falls during the period of intensified ISM. In a given year, the Indus, GBM and Irrawaddy rivers discharge approximately 238, 970, and $428 \mathrm{~km}^{3} \mathrm{yr}^{-1}$ water, respectively, to the Arabian Sea, the Bay of Bengal and the Andaman Sea (Gleik 1993). These discharge estimates suggest that under the current climate conditions, the Indus River discharges only $\sim 15 \%$ of the ISM. If there was a change in the intensity of the ISM, 
responses in the sea-surface proxy of the eastern Arabian Sea would therefore be relatively weak. Furthermore, other factors such as the intensity of the upwelling, foraminiferal depth-habitat, etc., would complicate the $\delta^{18} \mathrm{O}$ signal in the eastern Arabian Sea. It is not surprising therefore that $\delta^{18} \mathrm{O}$ records in planktonic foraminifera from the Indus delta do not reveal abrupt changes even though there were known drastic changes in the entire ISM system. On the other hand, a reduction in precipitation over the GBMI catchments should explicitly be reflected in $\delta^{18} \mathrm{O}_{\mathrm{sw}}$ records from the Andaman Sea and Bay of Bengal. We therefore propose that dramatic changes in ISM, as indicated in our $\delta^{18} \mathrm{O}_{\mathrm{sw}}$ records decreased the amount of precipitation over the entire region, including the Indus Valley, and may have forced the Indus Valley Civilizations to abandon their settlements.

\section{CONCLUDING REMARKS}

Sea-floor sedimentary records from the Bay of Bengal and Andaman Sea indicate that the Indian summer monsoon has undergone abrupt changes during the last $30 \mathrm{ka}$. The temporal resolution of our data is coarse in comparison to other Indian and Asian monsoons records such as Dongge, Hulu or Timta (Sinha et al. 2005) caves, however our records capture major reorganization events. Enriched seawater $\delta^{18} \mathrm{O}$ values both in the Bay of Bengal and Andaman Sea during the interval from 18.2 to $14.8 \mathrm{ka}$ and the YD suggest that the GBMI catchments received less precipitation and/ or direct less rainfall. As a result, the outflow from these rivers was diminished. The most depleted $\delta^{18} \mathrm{O}_{\mathrm{sw}}$ values in the early Holocene suggest that the ISM was strong resulting in significant precipitation. Our depleted $\delta^{18} \mathrm{O}_{\mathrm{sw}}$ values during the LGM suggest that the Bay of Bengal and the Andaman Sea was wetter in contrast to the commonly held view of dry climate for this period. A southward displacement of the mean position of the Intertropical Convergence Zone coupled with less summer (July) solar insolation during these periods could reduce precipitation and hence less GMBI outflow. Contrastingly, a warmer climate ushered in due to the retreat of the Tibetan glaciers in the early Holocene and enhanced summer solar insolation. An increase in evaporation from the tropical Indian Ocean and a strong land-ocean pressure gradient induced more moisture transport to India, as revealed by depleted seawater $\delta^{18} \mathrm{O}_{\mathrm{sw}}$ values.

The glacial climate of the Bay of Bengal and Andaman Sea was occasionally punctuated by $\delta^{18} \mathrm{O}$-depleted events. Whether these events can be correlated to the DansgaardOeschger events (Rasmussen et al. 2006) or the Chinese cave records (Wang et al. 2008) could not be ascertained due to the lack of finer temporal resolution and inadequate dating constraint. It is worthy of note that sediment cores used in this study were narrow diameter cores collected in 1969 and 1971 and the sediments have dried out. New cores are needed to generate decadal to centennial-scale ISM climate records, comparable to the cave and ice cores records of the Chinese speleothems and Tibetan Plateau, respectively.

The climate records from Bay of Bengal and Andaman Sea are generally similar however there are some differences, especially in the deglacial records, which is expanded in the Andaman Sea compared to the Bay of Bengal. Whether the expanded interval means that the GBM outflow is climatically more sensitive than that of the Irrawaddy remains to be investigated. Further, the transition between the glacial and $\mathrm{B} / \mathrm{A}$ periods in the Bay of Bengal was associated with a higher input of fine-grained sediments. Whether the GBM outflow carried more fine-grained sediments at the onset of a warmer climate or the outflow reached farther offshore is not yet understood. A depth transect of sediment cores from the lower shelf to slope may provide answers to these questions.

In the late Holocene, the Indian subcontinent witnessed abandonment of two of the greatest ancient civilizations. We hypothesize that this abandonment of the settlement may be linked to the onset of dry climate stemming from the weakened ISM at $5.2 \mathrm{ka}$. However, a precise timing of the onset and the duration of this event needs to be constrained.

Acknowledgements Harunur Rashid was supported by the Byrd Polar Fellowship and a seed grant from the Climate, Water and Carbon (CWC) program of The Ohio State University. $\mathrm{H}$. Rashid wishes to acknowledge technical support of E. Goddard (USF) in acquiring part of the $\mathrm{Mg} / \mathrm{Ca}$ data for this study. M. Smith and R. Gray are thanked for carefully reading the initial version of the manuscript.

\section{REFERENCES}

Adkins, J. F., K. McIntyre, and D. P. Schrag, 2002: The salinity, temperature, and $\delta^{18} \mathrm{O}$ of the glacial deep ocean. Science, 298, 1769-1773, doi: 10.1126/science. 1076252. [Link]

Anand, P., H. Elderfield, and M. H. Conte, 2003: Calibration of $\mathrm{Mg} / \mathrm{Ca}$ thermometry in planktonic foraminifera from a sediment trap time series. Paleoceanography, 18, 1050, doi: 10.1029/2002PA000846. [Link]

Anand, P., D. Kroon, A. D. Singh, R. S. Ganeshram, G. Ganssen, and H. Elderfield, 2008: Coupled sea surface temperature-seawater $\delta^{18} \mathrm{O}$ reconstructions in the Arabian Sea at the millennial scale for the last $35 \mathrm{ka}$. Paleoceanography, 23, PA4207, doi: 10.1029/2007PA001564. [Link]

Arz, H. W., F. Lamy, and J. Pätzold, 2006: A pronounced dry event recorded around $4.2 \mathrm{ka}$ in brine sediments from the northern Red Sea. Quat. Res., 66, 432-441, doi: 10.1016/j.yqres.2006.05.006. [Link]

Barnett, T. P., L. Dümenil, U. Schlese, and E. Roeckner, 1988: The effect of Eurasian snow cover on global climate. Science, 239, 504-507, doi: 10.1126/science. 
239.4839.504. [Link]

Barrows, T. T. and S. Juggins, 2005: Sea-surface temperatures around the Australian margin and Indian Ocean during the Last Glacial Maximum. Quat. Sci. Rev., 24, 1017-1047, doi: 10.1016/j.quascirev.2004.07.020. [Link]

Bond, G., W. Broecker, S. Johnsen, J. McManus, L. Labeyrie, J. Jouzel, and G. Bonani, 1993: Correlations between climate records from North Atlantic sediments and Greenland ice. Nature, 365, 143-147, doi: 10.1038/365143a0. [Link]

Boyle, E. A. and L. D. Keigwin, 1985/86: Comparison of Atlantic and Pacific paleochemical records for the last 215000 years: Changes in deep ocean circulation and chemical inventories. Earth Planet. Sci. Lett., 76, 135150, doi: 10.1016/0012-821X(85)90154-2. [Link]

Broccoli, A. J., K. A. Dahl, and R. J. Stouffer, 2006: Response of the ITCZ to Northern Hemisphere cooling. Geophys. Res. Lett., 33, L01702, doi: 10.1029/2005GL024546. [Link]

Cane, M. A., 2010: Climate: A moist model monsoon. $\mathrm{Na}$ ture, 463, 163-164, doi: 10.1038/463163a. [Link]

Chen, J., J. W. Farrell, D. W. Murray, and W. L. Prell, 1995: Timescale and paleoceanographic implications of a 3.6 m.y. oxygen isotope record from the northeast Indian Ocean (Ocean Drilling Program Site 758). Paleoceanography, 10, 21-47, doi: 10.1029/94PA02290. [Link]

CLIMAP Project Members, 1981: Seasonal Reconstructions of the Earth's Surface at the Last Glacial Maximum. Geol. Soc. Amer. Map Chart Ser. MC-36, 1-18.

Cullen, H. M., P. B. deMenocal, S. Hemming, G. Hemming, F. H. Brown, T. Guilderson, and F. Sirocko, 2000: Climate change and the collapse of the Akkadian empire: evidence from the deep sea. Geology, 28, 379-382, doi: 10.1130/0091-7613(2000)28<379:CCATCO>2.0.CO; 2. [Link]

Cullen, J. L., 1981: Microfossil evidence for changing salinity patterns in the Bay of Bengal over the last 20000 years. Palaeogeogr. Palaeoclimatol. Palaeoecol., 35, 315-356, doi: 10.1016/0031-0182(81)90101-2. [Link]

Delaygue, G., E. Bard, C. Rollion, J. Jouzel, M. Stiévenard, J.-C. Duplessy, and G. Ganssen, 2001: Oxygen isotope/ salinity relationship in the northern Indian Ocean. $J$. Geophys. Res., 106, 4565-4574, doi: 10.1029/1999JC 000061. [Link]

deMenocal, P., J. Ortiz, T. Guilderson, and M. Sarnthein, 2000: Coherent high- and low-latitude climate variability during the Holocene warm period. Science, $\mathbf{2 8 8}$, doi: 10.1126/science.288.5474.2198. [Link]

Duplessy, J. C., 1982: Glacial to interglacial contrasts in the northern Indian Ocean. Nature, 295, 494-498, doi: 10.1038/295494a0. [Link]

Elderfield, H. and G. Ganssen, 2000: Past temperature and $\delta^{18} \mathrm{O}$ of surface ocean waters inferred from fora- miniferal $\mathrm{Mg} / \mathrm{Ca}$ ratios. Nature, 405, 442-445, doi: 10.1038/35013033. [Link]

Fairbanks, R. G., 1989: A 17000-year glacio-eustatic sea level record: Influence of glacial melting rates on the Younger Dryas event and deep-ocean circulation. $\mathrm{Na}$ ture, 342, 637-642, doi: 10.1038/342637a0. [Link]

Fleitmann, D., S. J. Burns, M. Mudelsee, U. Neff, J. Kramers, A. Mangini, and A. Matter, 2003: Holocene forcing of the Indian monsoon recorded in a stalagmite from southern oman. Science, 300, 1737-1739, doi: 10.1126/science.1083130. [Link]

Gadgil, S., 2003: The Indian Monsoon and its variability. Annu. Rev. Earth Planet. Sci., 31, 429-467, doi: 10.1146/annurev.earth.31.100901.141251. [Link]

Gasse, F. and C. N. Roberts, 2005: Late Quaternary hydrologic changes in the arid and semi-arid belt of northern Africa. In: Diaz, H. F. and R. S. Bradley (Eds.), The Hadley Circulation: Present, Past and Future, Kluwer Acad. Pub., 313-345.

Gleik, P. H., 1993, Water in Crisis: A Guide to the World's Fresh Water Resources. Oxford University Press, 504 pp.

Gupta, A. K., M. Das, and D. M. Anderson, 2005: Solar influence on the Indian summer monsoon during the Holocene. Geophys. Res. Lett., 32, L17703, doi: 10.1029/2005GL022685. [Link]

Han, W., X. Fang, S. Yang, and J. King, 2010: Differences between East Asian and Indian monsoon climate records during MIS3 attributed to differences in their driving mechanisms: Evidence from the loess record in the Sichuan basin, southwestern China and other continental and marine climate records. Quat. Int., 218, 94103, doi: 10.1016/j.quaint.2010.01.002. [Link]

Hastenrath, S. and L. Greischar, 1993: The monsoonal heat budget of the hydrosphere-atmosphere system in the Indian Ocean sector. J. Geophys. Res., 98, 6869-6881, doi: 10.1029/92JC02956. [Link]

Heinz, P. and C. Hemleben, 2006: Foraminiferal response to the Northeast Monsoon in the western and southern Arabian Sea. Mar. Micropaleontol., 58, 103-113, doi: 10.1016/j.marmicro.2005.10.001. [Link]

Honjo, S., J. Dymond, W. Prell, and V. Ittekkot, 1999: Monsoon-controlled export fluxes to the interior of the Arabian Sea. Deep-Sea Res. II, 46, 1859-1902, doi: 10.1016/S0967-0645(99)00047-8. [Link]

Hut, G., 1987: Consultants' Group Meeting on Stable Isotope Reference Samples for Geochemical and Hydrological Investigations: IAEA, Vienna 16-18 September 1985: Report to the Director General, 42 pp., International Atomic Energy Agency, Vienna.

Kageyama, M., J. Mignot, D. Swingedouw, C. Marzin, R. Alkama, and O. Marti, 2009: Glacial climate sensitivity to different states of the Atlantic Meridional Overturning Circulation: Results from the IPSL model. Clim. 
Past, 5, 551-570, doi: 10.5194/cp-5-551-2009. [Link]

Kenoyer, J. M., 1998: Ancient Cities of the Indus Valley Civilization, Oxford University Press, Karachi, 264 pp.

Kienast, M., S. Steinke, K. Stattegger, and S. E. Calvert, 2001: Synchronous tropical South China Sea SST change and Greenland warming during deglaciation. Science, 291, 2132-2134, doi: 10.1126/science.1057131. [Link]

Kudrass, H. R., A. Hofmann, H. Doose, K. Emeis, and H. Erlenkeuser, 2001: Modulation and amplification of climatic changes in the Northern Hemisphere by the Indian summer monsoon during the past 80 k.y. Geology, 29, 63-66, doi: 10.1130/0091-7613(2001)029<00 63:MAAOCC >2.0.CO;2. [Link]

Kutzback, J. E. and F. A. Street-Perrot, 1985: Milankovitch forcing of fluctuations in the level of tropical lakes from 18 to 0 kyr BP. Nature, 317, 130-134, doi: 10.1038/317130a0. [Link]

Lamb, H. F., F. Gasse, A. Benkaddour, N. E. Hamouti, S. van der Kaars, W. T. Perkins, N. J. Pearce, and C. N. Roberts, 1995: Relation between century-scale Holocene arid intervals in tropical and temperate zones. $\mathrm{Na}$ ture, 373, 134-137, doi: 10.1038/373134a0. [Link]

Laskar, J., 1990: The chaotic motion of the solar system: A numerical estimate of the size of the chaotic zones. Icarus, 88, 266-291, doi: 10.1016/0019-1035(90)90084-M. [Link]

Lea, D. W., D. K. Pak, and H. J. Spero, 2000: Climate impact of late Quaternary equatorial Pacific sea surface temperature variations. Science, 289, 1719-1724, doi: 10.1126/science.289.5485.1719. [Link]

Levermann, A., J. Schewe, V. Petoukhov, and H. Held, 2009: Basic mechanism for abrupt monsoon transitions. Proc. Natl. Acad. Sci. USA, 106, 20572-20577, doi: 10.1073/pnas.0901414106. [Link]

Levitus, S. and T. P. Boyer, 1994: World Ocean Atlas 1994, vol.3, Salinity, NOAA Atlas NESDIS 3, 99 pp, NOAA, Silver Spring, MD.

Madella, M. and D. Q. Fuller, 2006: Palaeoecology and the Harappan Civilisation of South Asia: A reconsideration. Quat. Sci. Rev., 25, 1283-1301, doi: 10.1016/j. quascirev.2005.10.012. [Link]

Maxwell, A. L., 2001: Holocene monsoon changes inferred from lake sediment pollen and carbonate records, northeastern Cambodia. Quat. Res., 56, 390-400, doi: 10.1006/qres.2001.2271. [Link]

Mohtadi, M., A. Lückge, S. Steinke, J. Groeneveld, D. Hebbeln, and N. Westphal, 2010: Late Pleistocene surface and thermocline conditions of the eastern tropical Indian Ocean. Quat. Sci. Rev., 29, 887-896, doi: 10.1016/j. quascirev.2009.12.006. [Link]

Monnin, E., A. Indermühle, A. Dällenbach, J. Flückiger, B. Stauffer, T. F. Stocker, D. Raynaud, and J.-M. Barnola, 2001: Atmospheric $\mathrm{CO}_{2}$ concentrations over the last glacial termination. Science, 291, 112-114, doi: 10.1126/science.291.5501.112. [Link]

Morrill, C., J. T. Overpeck, and J. E. Cole, 2003: A synthesis of abrupt changes in the Asian summer monsoon since the last deglaciation. Holocene, 13, 465-476, doi: 10.1191/0959683603hl639ft. [Link]

Mulitza, S., D. Boltovskoy, B. Donner, H. Meggers, A. Paul, and G. Wefer, 2003: Temperature: $\delta^{18} \mathrm{O}$ relationships of planktonic foraminifera collected from surface waters. Palaeogeogr. Palaeoclimatol. Palaeoecol., 202, 143-152, doi: 10.1016/S0031-0182(03)00633-3. [Link]

Mulitza, S., M. Prange, J.-B. Stuut, M. Zabel, T. von Dobeneck, A. C. Itambi, J. Nizou, M. Schulz, and G. Wefer, 2008: Sahel megadroughts triggered by glacial slowdowns of Atlantic meridional overturning. Paleoceanography, 23, PA4206, doi: 10.1029/2008PA001637. [Link]

Murata, F., T. Terao, T. Hayashi, H. Asada, and J. Matsumoto, 2008: Relationship between atmospheric conditions at Dhaka, Bangladesh, and rainfall at Cherrapunjee, India. Nat. Hazards, 44, 399-410, doi: 10.1007/s11 069-007-9125-2. [Link]

Naidu, P. D. and B. A. Malmgren, 1995: A 2200 year periodicity in the Asian monsoon system. Geophys. Res. Lett., 22, 2361-2364, doi: 10.1029/95GL02558. [Link]

Overpeck, J., D. Anderson, S. Trumbore, and W. Prell, 1996: The southwest Indian monsoon over the last 18000 years. Climate Dyn., 12, 213-225, doi: 10.1007/ BF00211619. [Link]

Peixóto, J. P. and A. H. Oort, 1983: The atmospheric branch of the hydrological cycle and climate. In: Street-Perrot, F. A., M. Beran, and R. Ratcliffe (Eds.), Variations in the Global Water Budget, D. Reidel Publ. Co., Dordrecht, Holland, $518 \mathrm{pp}$.

Perry, G. D., P. B. Duffy, and N. L. Miller, 1996: An extended data set of river discharges for validation of general circulation models. J. Geophys. Res., 101, 21339 -21349, doi: 10.1029/96JD00932. [Link]

Phadtare, N. R., 2000: Sharp decrease in summer monsoon strength 4000-3500 cal yr B.P. in the central Higher Himalaya of India based on pollen evidence from alpine peat. Quat. Res., 53, 122-129, doi: 10.1006/qres. 1999.2108. [Link]

Philander, S. G. H., D. Gu, G. Lambert, T. Li, D. Halpern, N.-C. Lau, and R. C. Pacanowski, 1996: Why the ITCZ is mostly north of the equator. J. Climate, 9, 29582972, doi: 10.1175/1520-0442(1996)009<2958:WTII MN>2.0.CO;2. [Link]

Porter, S. C. and Z. An, 1995: Correlation between climate events in the North Atlantic and China during the last glaciation. Nature, 375, 305-308, doi: 10.1038/375305 a0. [Link]

Possehl, G. L., 2002: The Indus Civilization: A Contemporary Perspective. AtlaMira Press, Lanham, 288 pp. 
Rao, V. P., P. M. Kessarkar, M. Thamban, and S. K. Patil, 2010: Paleoclimatic and diagenetic history of the late Quaternary sediments in a core from the southeastern Arabian Sea: Geochemical and magnetic signals. $J$. Oceanogr., 66, 133-146, doi: 10.1007/s 10872-010-00 11-2. [Link]

Rashid, H. and E. A. Boyle, 2004: A 100 Kyr SST record based on the $\mathrm{Mg} / \mathrm{Ca}$ of Neogloboquadrina pachyderma (s) from the Labrador Sea. Eos, Trans., AGU, 85, PP23B-1407.

Rashid, H. and E. A. Boyle, 2008: Response to comment on "Mixed-Layer deepening during Heinrich events: A multi-planktonic foraminiferal $\delta^{18} \mathrm{O}$ approach." Science, 320, p 1161, doi: 10.1126/science.1153646. [Link]

Rashid, H., B. P. Flower, and T. M. Quinn, 2006: Tropical Indian Ocean paleoclimatic history over the last 173000 years. Eos, Trans., AGU, 87, PP31B-1748.

Rashid, H., B. P. Flower, R. Z. Poore, and T. M. Quinn, 2007: A 25 ka Indian Ocean monsoon variability record from the Andaman Sea. Quat. Sci. Rev., 26, 25862597, doi: 10.1016/j.quascirev.2007.07.002. [Link]

Rasmussen, S. O., K. K. Andersen, A. M. Svensson, J. P. Steffensen, B. M. Vinther, H. B. Clausen, M.-L. Siggaard-Andersen, S. J. Johnsen, L. B. Larsen, D. Dahl-Jensen, M. Bigler, R. Röthlisberger, H. Fischer, K. Goto-Azuma, M. E. Hansson, and U. Ruth, 2006: A new Greenland ice core chronology for the last glacial termination. J. Geophys. Res., 111, D06102, doi: 10.1029/2005JD006079. [Link]

Reimer, P. J., M. G. L. Baillie, E. Bard, A. Bayliss, J. W. Beck, P. G. Blackwell, C. B. Ramsey, C. E. Buck, G. S. Burr, R. L. Edwards, M. Friedrich, P. M. Grootes, T. P. Guilderson, I. Hajdas, T. J. Heaton, A. G. Hogg, K. A. Hughen, K. F. Kaiser, B. Kromer, F. G. McCormac, S. W. Manning, R. W. Reimer, D. A. Richards, J. R. Southon, S. Talamo, C. S. M. Turney, J. van der Plicht, and C. Weyhenmeyer, 2009: IntCa109 and Marine09 radiocarbon age calibration curves, 0-50000 years cal BP. Radiocarbon, 51, 1111-1150.

Robock, A., M. Mu, K. Vinnikov, and D. Robinson, 2003: Land surface conditions over Eurasia and Indian summer monsoon rainfall. J. Geophys. Res., 108, 4131, doi: 10.1029/2002JD002286. [Link]

Rosenthal, Y., D. W. Oppo, and B. K. Linsley, 2003: The amplitude and phasing of climate change during the last deglaciation in the Sulu Sea, western equatorial Pacific. Geophys. Res. Lett., 30, 1428, doi: 10.1029/2002GL016612. [Link]

Saher, M. H., S. J. A. Jung, H. Elderfield, M. J. Greaves, and D. Kroon, 2007: Sea surface temperatures of the western Arabian Sea during the last deglaciation. Paleoceanography, 22, PA2208, doi: 10.1029/2006PA001292. [Link]
Schmiedl, G. and A. Mackensen, 2006: Multispecies stable isotopes of benthic foraminifers reveal past changes of organic matter decomposition and deepwater oxygenation in the Arabian Sea. Paleoceanography, 21, PA4213, doi: 10.1029/2006PA001284. [Link]

Schulz, H., U. von Rad, and H. Erlenkeuser, 1998: Correlation between Arabian Sea and Greenland climate oscillations of the past 110000 years. Nature, 393, 54-57, doi: 10.1038/31750. [Link]

Severinghaus, J. P., R. Beaudette, M. A. Headly, K. Taylor, and E. J. Brook, 2009: Oxygen-18 of $\mathrm{O}_{2}$ records the impact of abrupt climate change on the terrestrial biosphere. Science, 324, 1431-1434, doi: 10.1126/science.1169473. [Link]

Shankar, D., P. N. Vinayachandran, and A. S. Unnikrishnan, 2002: The monsoon currents in the north Indian Ocean. Prog. Oceanogr., 52, 63-120, doi: 10.1016/S00 79-6611(02)00024-1. [Link]

Sharma, S., M. Joachimski, M. Sharma, H. J. Tobschall, I. B. Singh, C. Sharma, M. S. Chauhan, and G. Morgenroth, 2004: Lateglacial and Holocene environmental changes in Ganga plain, Northern India. Quat. Sci. Rev., 23, 145-159, doi: 10.1016/j.quascirev.2003.10.005. [Link]

Sinha, A., K. G. Cannariato, L. D. Stott, H. C. Li, C. F. You, H. Cheng, R. L. Edwards, and I. B. Singh, 2005: Variability of southwest Indian summer monsoon precipitation during the Bølling-Ållerød. Geology, 33, 813816, doi: 10.1130/G21498.1. [Link]

Sonzogni, C., E. Bard, and F. Rostek, 1998: Tropical seasurface temperatures during the last glacial period: A view based on alkenones in Indian Ocean sediments. Quat. Sci. Rev., 17, 1185-1201, doi: 10.1016/S02773791(97)00099-1. [Link]

Southon, J., M. Kashgarian, M. Fontugne, B. Metivier, and W.-S. Yim, 2002: Marine reservoir corrections for the Indian Ocean and Southeast Asia. Radiocarbon, 44, 167-180.

Staubwasser, M., F. Sirocko, P. M. Grootes, and M. Segl, 2003: Climate change at the $4.2 \mathrm{ka} \mathrm{BP}$ termination of the Indus valley civilization and Holocene south Asian monsoon variability. Geophys. Res. Lett., 30, 1425, doi: 10.1029/2002GL016822. [Link]

Steinke, S., H. Y. Chiu, P. S. Yu, C. C. Shen, H. Erlenkeuser, L. Löwemark, and M. T. Chen, 2006: On the influence of sea level and monsoon climate on the southern South China Sea freshwater budget over the last 22000 years. Quat. Sci. Rev., 25, 1475-1488, doi: 10.1016/j. quascirev.2005.12.008. [Link]

Steinke, S., M. Kienast, J. Groeneveld, L. C. Lin, M. T. Chen, and R. Rendle-Bühring, 2008: Proxy dependence of the temporal pattern of deglacial warming in the tropical South China Sea: Toward resolving seasonality. Quat. Sci. Rev., 27, 688-700, doi: 10.1016/j. quascirev.2007.12.003. [Link] 
Stott, L., C. Poulsen, S. Lund, and R. Thunell, 2002: Super ENSO and global climate oscillations at millennial time scales. Science, 297, 222-226, doi: 10.1126/science. 1071627. [Link]

Swain, A. M., J. E. Kutzbach, and S. Hastenrath, 1983: Estimates of Holocene precipitation for Rajasthan, India, based on pollen and lake-level data. Quat. Res., 19, 1-17, doi: 10.1016/0033-5894(83)90024-8. [Link]

Thompson, L. G., T. Yao, M. E. Davis, K. A. Henderson, E. Mosley-Thompson, P.-N. Lin, J. Beer, H.-A. Synal, J. Cole-Dai, J. F. Bolzan, 1997: Tropical climate instability: The last glacial cycle from a Qinghai-Tibetan ice core. Science, 276, 1821-1825, doi: 10.1126/scien ce.276.5320.1821. [Link]

Thompson, L. G., E. Mosley-Thompson, M. E. Davis, K. A. Henderson, H. H. Brecher, V. S. Zagorodnov, T. A. Mashiotta, P.-N. Lin, V. N. Mikhalenko, D. R. Hardy, and J. Beer, 2002: Kilimanjaro ice core records: Evidence of Holocene climate change in Tropical Africa. Science, 298, 589-593, doi: 10.1126/science.1073198. [Link]

Thompson, L. G., E. Mosley-Thompson, H. Brecher, M. Davis, B. León, D. Les, P.-N. Lin, T. Mashiotta, and K. Mountain, 2006: Abrupt tropical climate change: Past and present. Proc. Natl. Acad. Sci. USA, 103, 1053610543, doi: 10.1073/pnas.0603900103. [Link]

Trenberth, K. E. and C. J. Guillemot, 1998: Evaluation of the atmospheric moisture and hydrological cycle in the NCEP/NCAR reanalyses. Climate Dyn., 14, 213-231, doi: 10.1007/s003820050219. [Link]

van Campo, E., J. C. Duplessy, and M. Rossignol-Strick,
1982: Climatic conditions deduced from a 150-kyr oxygen isotope-pollen record from the Arabian Sea. Nature, 296, 56-59, doi: 10.1038/296056a0. [Link]

Visser, K., R. Thunell, and L. Stott, 2003: Magnitude and timing of temperature change in the Indo-Pacific warm pool during deglaciation. Nature, 421, 152-155, doi: 10.1038/nature01297. [Link]

Wang, Y., H. Cheng, R. L. Edwards, Y. He, X. Kong, Z. An, J. Wu, M. J. Kelly, C. A. Dykoski, and X. Li, 2005: The Holocene Asian monsoon: Links to solar changes and north Atlantic climate. Science, 308, 854-857, doi: 10.1126/science.1106296. [Link]

Wang, Y., H. Cheng, R. L. Edwards, X. Kong, X. Shao, S. Chen, J. Wu, X. Jiang, X. Wang and Z. An, 2008: Millennial- and orbital-scale changes in the East Asian monsoon over the past 224000 years. Nature, 451, 1090-1093, doi: 10.1038/nature06692. [Link]

Webster, P. J., V. O. Magaña, T. N. Palmer, J. Shukla, R. A. Tomas, M. Yanai, and T. Yahunari, 1998: Monsoons: Processes, predictability, and the prospects for prediction. J. Geophys. Res., 103, 14451-14510, doi: 10.1029/97JC02719. [Link]

Weiss, H., M.-A. Courty, W. Wetterstrom, F. Guichard, L. Senior, R. Meadow, and A. Curnow, 1993: The Genesis and collapse of third millennium north Mesopotamian civilization. Science, 261, 995-1004, doi: 10.1126/science.261.5124.995. [Link]

Yadava, M. G. and R. Ramesh, 2005: Monsoon reconstruction from radiocarbon dated tropical Indian speleothems. Holocene, 15, 48-59, doi: 10.1191/095968360 5h1783rp. [Link] 